\title{
The Common Challenges of Brand Equity Creation among Local Fast Food Brands in Malaysia
}

\author{
Teck Ming $\operatorname{Tan}^{1}$, Rasiah Devinaga ${ }^{2} \&$ Ismail Hishamuddin $^{2}$ \\ ${ }^{1}$ Centre for Diploma Programme, Multimedia University, Melaka, Malaysia \\ ${ }^{2}$ Faculty of Business and Law, Multimedia University, Melaka, Malaysia \\ Correspondence: Teck Ming Tan, Centre for Diploma Programme, Multimedia University, and Melaka, Malaysia.
}

Tel: 60-6-252-3091. E-mail: tan@brandattachment.com

Received: August 16, 2012 Accepted: December 26, 2012 Online Published: December 28, 2012

doi:10.5539/ijbm.v8n2p96 URL: http://dx.doi.org/10.5539/ijbm.v8n2p96

\begin{abstract}
This study reflects on the need to examine the challenges of brand equity creation among Malaysian fast food brands. There was a need to observe brand awareness which contributes greater variance on brand trust, attitudinal brand loyalty, and overall brand equity than perceived quality across global and Malaysian brands. The main purpose of this study was to provide a better management practices for branding strategy and brand tracking; highlighting the natural drawbacks on focusing the perception of brand quality that have been exercised by many Malaysian fast food brands. The result of this study reveals that the dimensions of consumer-based brands equity could be reasonably related to category specific.
\end{abstract}

Keywords: brand equity, category specific, fast food, perceived quality, brand awareness, Malaysia

\section{Introduction}

Brand is defined as the identity of a specific product, service, or business and it could take many forms, including a name, sign, symbol, colour combination or slogan (Aaker, 1991). As compared to other types and concepts of restaurant business, such as mid-scale restaurant, upscale restaurant, and café, fast food restaurants had gathered greater interest in building a strong brand because the products and services were not naturally differentiated (Tan et al., 2011). Global brands, such as McDonald's, KFC, and Pizza Hut are excellent in brand management; this is because they had invested in branding and marketing research, to ensure that their brand value was consistently aligned with the corporate objectives. Conversely, Malaysian brands such as Marrybrown and 1901 Hot Dog did not execute well in the development of brand equity. This could be evidenced by the high percentage of market share as dominated by global fast food brands (Aseambankers, 2007). Conventionally, Malaysian fast food brands had exclusively focused on the consumers' perception of utility added value, such as food quality, physical environment, modern equipment, service quality, and privileges program. Ultimately, Malaysian brands were not successful in brand equity creation due to insufficient direction on branding strategy. The main purpose of this study is to reflect on the common challenges of brand equity creation among Malaysian fast food brands that had enjoyed perceived quality, brand trust and attitudinal brand loyalty. The study also extends the effect of category into the theoretical view of consumer-based brand equity, which had provided a better guidance for fast food brand management.

\section{Literature Review}

\subsection{Global and Malaysian Fast Food Brands}

Fast food brand was defined as restaurants that provided expedited food service, which offered western pattern diet, established standard operating procedures, and had franchises in multiple states or nationwide (Ashkanasy \& Nicholson, 2003; Block et al., 2004; Burdette \& Whitaker, 2004; Slattery et al., 1998). Over the years, Global brands such as McDonald's, KFC, and Pizza Hut had gained strong brand preference and brand awareness (Tan et al., 2011); this was supported by high numbers of Facebook fans and interactions for global fast food brands when compared to Malaysian brands (Tan, 2012), and 82\% of Malaysian fast food market share was dominated by global brands (Aseambankers, 2007). According to BrandEquity (2011), fast food centers had spent about RM149 million in advertising across media in 2010, ranking first in the Malaysian retail category with the growth rate of $28.4 \%$, and most of the percentage was contributed by global brands. Hafidz et al. (2010) stated 
that McDonald had increased $27 \%$ of its advertising and promotional spending while KFC went up by $7 \%$. In addition, global brands had dramatically expanded the numbers of outlets in years 2011, which had promoted greater coverage of services such as breakfast, lunch, dinner, 24-hour service and drive through. On the other hand, Malaysian brands such as 1901 Hot Dogs only had 91 outlets across Malaysia; it has been 11 years since incorporation according to (Kam, 2008), while Marrybrown consisted of 250 outlets after 30 years of business (The Star, 2010). Unlike these success stories, there are many Malaysian fast food brands that lacked the expertise in branding and marketing (Marshall Cavendish, 2009).

\subsection{Effect of Category on the Variation of Consumer-Based Brand Equity}

Fast food brand equity has always been a multidimensional concept. It is made of perceived quality, brand awareness, brand familiarity, brand image, and attitudinal brand loyalty (Tan et al., 2011). Despite the fact of low concentration on branding among Malaysian brands, this study does not assume that global brands would significantly have greater evaluation on all dimensions of brand equity when compared to Malaysian brands. The motivation of this study was to look at the variation that affected different categories of brand equity dimensions while considering the brand origin. According to the categorization approach, these objects could be grouped into varying levels of specificity (Sujan \& Dekleva, 1987), and brand could be reasonably explained as an object. In this study, it was assumed that the variation of overall brand equity and brand awareness would be determined by marketing effort on category specification. Conversely, there is no category which influenced perceived quality, brand trust and attitudinal brand loyalty. Both brand familiarity and brand image was excluded to reach the simplification of research design.

Psychological-based approaches had indicated that overall brand equity was seen as a node in the memory with different types of associations, varying in strength, and linked together. According to Loken and Roedder (1993), this approach assumed that consumers would connect to a brand by category specific, based on its specific attributes with different types of association that represented in the mind of consumers. Valkenburg and Buijzen (2005) suggested that brand awareness was commonly referred to as an individual's active and passive knowledge of a specific brand. It was the consumers' ability to associate a brand with its category, which referred to the strength of a brand's presence in the consumer's mind (Aaker, 1996). Brand awareness in addition was referred to the ability of consumers to recover or regain the brand when given some cues, such as category (Keller, 1998). To be precise, individuals would specify a particular brand name, without further delay when given the category cue. As a result, the connection in between the level of consumers' knowledge with the brand role on a specify category served as the most important criteria to determine the level of overall brand equity and brand awareness.

In Malaysia, there were numerous global fast food marketing and promotions carried out that is focused on specific categories, for instance McDonald's Weekday Breakfast Special (breakfast), McValue Lunch \& Dinner (lunch and dinner), Happy Meal (kids), KFC AM (breakfast), KFC Jom Jimat, (lunch), Chicky Meal (kids), Pizza Hut's Lunch Express (lunch), and Hut's Power Meals (lunch). Furthermore, most of the new products of global brands are highly related to the core product category, for example McDonald's Prosperity Burger, KFC Tom Yam Crunch, Golden Fortune Pizza and so on. When compared to the Malaysian brands, the products were excessively diversified into other categories; for example Marrybrown had extended their brand to chicken rice, porridge, fish and chips, fried chicken, and hamburger. Similarly, 1901 Hot Dog had broadened their hotdog concept to pizza. Consequently, consumers had difficulty in registering Malaysian fast food brands in their associative network memory due to the ambiguity on brand categorization. This had led to lower the level of the overall brand equity and brand awareness. Hence, the findings indicated that such differences in marketing and branding effort would be reflect in differences in results between global and Malaysian fast food brands, where global brands would enjoy greater levels of overall brand equity and brand awareness as they had considered the effect of category.

H1a: Respondents' overall brand equity levels for global fast food brands are significantly higher than Malaysian fast food brands.

H1b: Respondents' awareness levels for global fast food brands are significantly higher than Malaysian fast food brands.

Perceived quality was referred to as the overall perception of consumers towards the product or service of a brand (Zeithaml, 1988). Positive perceived quality resulted from the supremacy of perception and vice versa. Grönroos (1984) showed that consumers perceived quality through their first-hand experiences with the brand and also via information acquired from the surrounding environment. Research conducted by Michell et al. (2001) had further affirmed that quality, reliability, and performance had ranked first, second, and third positions 
respectively. Therefore, perceived quality was consistently proven as an essential quality criterion on the past-experience and evaluations (Tan et al., 2012a). That is, it could be enhanced by the actual interactions regardless of the consideration of category effect. As a result, the Malaysian brands had provided better service quality due to lesser daily transactions and peak hours; however, Malaysian brands had ensured greater levels of courtesy, responsiveness, and individual attention than global brands.

H1c: Respondents' perceived quality levels for Malaysian fast food brands were significantly higher than global fast food brands.

Anderson and Weitz $(1989$, p. 312) had referred to brand trust as "one party's belief that its needs would be fulfilled in the future by actions undertaken by the other party." Morgan and Hunt (1994, p. 23) stated that trust existed "when one party had confidence in an exchange partner's reliability and integrity." This could be further explained that the formation of trusted business relationships would be established when there was an understanding of exchanged partners in between the brand, apart from the thoughtfulness of specific category. Therefore, there was no significant difference in either brand trust between global and Malaysian brands as both brands had created an exchange of environment in which had provided consistent services (i.e. standard operating procedures) to their customers across different outlets, and indicated high reliability and integrity status of the brand itself (Tan et al., 2011).

\section{H1d: Respondents' trust levels for global and Malaysian fast food brands are not significantly different.}

There were two perspectives of brand loyalty, such as behavioral brand loyalty and attitudinal brand loyalty (Chaudhuri \& Holbrook, 2001). Attitudinal brand loyalty was adopted because it was based on consumers' commitment rather than consumers' actual purchase behavior (Bloemer \& Kasper, 1995). A consumer was defined as attitudinal loyalty when he or she had expressed a positive preference and psychological commitment towards a brand (Caruana, 2002), such as customer's intention of repeat purchase (Chiou \& Droge, 2006), recommendation to others (Russell-Bennett et al., 2007), low switching to better competitors (Narayandas, 1996), attachment (Back, 2005), or willingness to pay a price premium (Narayandas, 1996). Even though researchers had indicated that attitudinal brand loyalty as the closest element to the concept of brand equity, but their conceptualization did not include the explanation on category effect (Yoo et al., 2000; Zinnbauer \& Bakay, 2004). In other word, a consumer was defined as attitudinal loyally when he or she expressed positive preference and commitment towards a brand regardless of the consideration for category specification. At the same, he or she had maintained positive psychological commitment to the many targeted brands within the same product category, such as loyal to McDonald's and Burger King for hamburger. Thus, there would not be significantly being different among global and Malaysian brands, seeing that both brands had delivered loyalty programs for their customers via customer relationship management. Thus, strong brand-relationship could be derived from the frequent interactions between global or Malaysian brands with their consumers.

\section{H1e: Respondents' attitudinal loyalty levels for global and Malaysian fast food brands are not significantly different.}

\subsection{Effect of Perceived Quality and Brand Awareness on Consumer-Based Brand Equity}

Perceived quality was considered as an important measurement in the fast food industry because many social scientists had ensured that service quality was the primary cognitive assessment of service provider at the attribute level (Chiou et al., 2002; Dabholkar, 1995; Donovan et al., 1994). Positive perceived quality could influence consumers' selection, motivate consumers in making purchase decision, brand differentiation, positive word-of-mouth, and provide opportunity for charging a price premium (Aaker, 1991). On the other hand, brand awareness was considered as a vital dimension in the context of fast food industry as it was the prerequisite for brand equity (Heding et al., 2009). If the consumer was not aware of the brand, it was not relevant to talk about brand equity in the first place; then the company competed on the product rather than the brand (Aaker, 1991). Brand awareness could be evidenced, when the brand was strongly held in consumers' memory via consumer categorization processes (Keller, 2003). Therefore, it was reflected by an individual's ability to recognize and recall a variety of brand elements, such as the brand name, logo, symbol, character, packaging and slogan under different condition of category.

Although perceived quality was measured as a "core or primary" facet across the fast food industry (Tan et al., 2011), especially among the Malaysian brands as it had contributed to immediate results on sales revenue, such as re-purchase behavior and recommendation to others. But our findings suggested that brand awareness would contribute to long-term result instead of instantaneous sales revenue, which served as the greater sense to distinguish the dissimilarity of consumers' responsiveness between a focal brand and an unbranded fast food as compared to perceived quality. This was because brand awareness was the long-standing strength of a brand's 
presence in the consumer's mind for a specific category (Aaker, 1991). Furthermore, brand awareness was proven to have greater result on the fast food restaurants than perceived quality, such as the revenue sustainability (Kim \& Kim, 2005). Thus, our finding indicated that the high and low level of brand awareness would produce greater variance on brand trust, attitudinal brand loyalty, and overall brand equity than the effects of perceived quality across global and Malaysian fast food brands.

H2: The high (low) level of brand awareness would result greater variance on consumer-based brand equity as compared to high (low) level perceived quality

\section{Methodology}

Nine measurement items of perceived quality were adopted from Kim and Kim (2005) in their quick services restaurant study. Seven items of brand awareness were developed from Park (2009, p. 56), another item: "When I think about [fast food category], $\mathrm{X}$ is the first brand that comes to my mind" was adopted from Gil et al. (2007, p. 193). Brand trust was measured by four items that was adopted from Matzler et al. (2008, p. 156) and Park (2009, p. 57). Four items were adapted from Chiou and Droge (2006, p.625) to measure attitudinal brand loyalty. Overall brand equity was measured using four items from Gil et al. (2007, p.193). Due to the research hypotheses, the highlight of product category was specifically included in certain measurement items of brand awareness and overall brand equity, but was not indicated in perceived quality, brand trust, and attitudinal brand loyalty.

A preliminary study was conducted to select fast-food brands for the initial pilot study and followed by the main study, with an open-ended questionnaire addressed to 50 fast food consumers, containing a question such as "please list three fast food restaurant chains in which you had most frequently dined". The result showed that most Malaysian popular global fast food brands were McDonald's (hamburger and French fries), Kentucky Fried Chicken (fried chicken), Pizza Hut (pizza); and Malaysian brands were Marrybrown (fried chicken and chicken burger), and 1901 Hot Dogs (hot dog). Subsequently, a pilot study was conducted to evaluate the clarity of the questions, as well as the reliability and validity of the measurement items. The validity of the questionnaire was determined by academicians, who were experts in the area of branding studies. There were only minor amendments recommended by the experts, as most of the suggestions were related to the structure of the statements and English proficiency. A total number of 50 pilot surveys were collected via a nonprobability convenience sampling from fast food consumers. The range for Cronbach's Alpha was from 0.75 to 0.91, which satisfied the cut-off value needed, as it indicated the internal consistency for the constructs (Nunnally, 1978). Upon completion of the pilot study, a total number of 600 questionnaires were distributed for the main study as it was in line with the previous studies (Halim \& Hamed, 2005; Perez et al., 2011; Yoo et al., 2000), and with a sample size that was above the number of nonprobability convenience sampling as conducted by most of the recent studies that focused on brand equity (Buil et al., 2008; Cobb-Walgren et al., 1995; Esch et al., 2006; Henry et al., 2010; Lassar et al., 1995; Tong \& Hawley, 2009). Klang Valley, Malaysia was selected as it drew out the heterogeneous sample that constituted people from all ethnic groups and various demographic characteristics (Norzalita \& Norjaya, 2010). The questions were identical; only varied by the brand name and product category.

A multivariate analysis of variance (MANOVA) was carried out on the selected data as it was an extension to the analysis of variance on more than one dependent variable. In addition, it also provided the univariate results for each of the dependent variables separately. Another advantage of using MANOVA is that it controlled or adjusted for the increased of a Type 1 error, which overcomes the limitation of ANOVA (Pallant, 2005).

\section{Findings and Discussion}

A total number of 600 six-point scale questionnaires were distributed in the fast food restaurants via non-probability convenience sampling. Subsequent to the data screening process, 15 surveys were excluded due to incomplete responses, as there were unfinished measurement items. A total numbers of 54 multivariate outliers were identified by using the method recommended by Pallant (2005). Thus, 531 or $88.50 \%$ of respondents were proceeding for further analysis. Out of the pool of applicable survey forms, $49.74 \%$ were Malaysian brands (Marrybrown and 1901 Hotdogs) and 50.26\% were global brands (McDonalds', KFC and Pizza Hut). There were male $48.2 \%$ and female $51.8 \%$, which were equally distributed. With respect to ethnic groups, $64.6 \%$ were Malays, followed by Chinese $25.8 \%$, Indian $4.5 \%$, and others $5.1 \%$. In term of age group, $20.2 \%$ were less than 21 years old, $46.2 \%$ were in between 21 to 25 years old, and $33.6 \%$ were above 26 years old. 
Table 1. MANOVA results - univariate tests - within-subjects effects for global and Malaysian fast food brands

\begin{tabular}{lcccccccc}
\hline Dependent Variables & Mean & SD & N & F & df & Error df & p & Partial Eta Squared \\
\hline Perceived quality & & & & 13.71 & 1 & 529 & $0.00^{*}$ & 0.025 \\
Global brand & 4.26 & 0.82 & 264 & & & & & \\
Malaysian brand & 4.51 & 0.78 & 267 & & & & & \\
Brand awareness & & & & 70.90 & 1 & 529 & $0.00^{*}$ & 0.118 \\
Global brand & 4.78 & 0.83 & 264 & & & & & \\
Malaysian brand & 4.13 & 0.94 & 267 & & & & & 0.002 \\
Brand trust & & & & 1.09 & 1 & 529 & 0.30 & \\
Global brand & 4.44 & 0.94 & 264 & & & & & \\
Malaysian brand & 4.35 & 0.93 & 267 & & & & & \\
Attitudinal brand loyalty & & & & 2.99 & 1 & 529 & 0.08 & \\
Global brand & 4.19 & 0.97 & 264 & & & & & \\
Malaysian brand & 4.04 & 1.04 & 267 & & & & & \\
Overall Brand equity & & & & 9.54 & 1 & 529 & 0.006 & \\
Global brand & 4.23 & 1.01 & 264 & & & & & \\
Malaysian brand & 3.95 & 1.07 & 267 & & & & & \\
\hline
\end{tabular}

Notes: Multivariate tests significant at $0.000 ; \mathrm{F}=33.76(5,525)$; Partial Eta Squared $=0.243$

Significant at 0.01 level; $\mathrm{SD}=$ Standard deviation

Cronbach's alpha range from 0.902 to 0.937

Table 2. MANOVA results - univariate tests - within-subjects effects for global fast food brands

\begin{tabular}{|c|c|c|c|c|c|c|c|c|c|}
\hline Effects & Dependent Variables & Mean & SD & $\mathbf{N}$ & $F$ & $d f$ & Error $d f$ & $p$ & Partial Eta Squared \\
\hline \multirow{9}{*}{$\begin{array}{l}\text { Perceived } \\
\text { quality } \\
(P Q)\end{array}$} & Brand trust & & & & 49.07 & 3 & 260 & $0.00^{*}$ & 0.159 \\
\hline & High PQ & 4.80 & 0.07 & 132 & & & & & \\
\hline & Low PQ & 4.13 & 0.07 & 132 & & & & & \\
\hline & Attitudinal brand loyalty & & & & 45.92 & 3 & 260 & $0.00^{*}$ & 0.150 \\
\hline & High PQ & 4.57 & 0.07 & 132 & & & & & \\
\hline & Low PQ & 3.88 & 0.07 & 132 & & & & & \\
\hline & Overall Brand equity & & & & 35.03 & 3 & 260 & $0.00^{*}$ & 0.119 \\
\hline & High PQ & 4.60 & 0.08 & 132 & & & & & \\
\hline & Low PQ & 3.94 & 0.08 & 132 & & & & & \\
\hline \multirow{9}{*}{$\begin{array}{l}\text { Brand } \\
\text { awareness } \\
(B A)\end{array}$} & Brand trust & & & & 69.58 & 3 & 260 & $0.00^{*}$ & 0.211 \\
\hline & High BA & 4.87 & 0.07 & 132 & & & & & \\
\hline & Low BA & 4.07 & 0.07 & 132 & & & & & \\
\hline & Attitudinal brand loyalty & & & & 57.62 & 3 & 260 & $0.00^{*}$ & 0.181 \\
\hline & High BA & 4.61 & 0.07 & 132 & & & & & \\
\hline & Low BA & 3.84 & 0.07 & 132 & & & & & \\
\hline & Overall Brand equity & & & & 40.61 & 3 & 260 & $0.00^{*}$ & 0.135 \\
\hline & High BA & 4.62 & 0.08 & 132 & & & & & \\
\hline & Low BA & 3.91 & 0.08 & 132 & & & & & \\
\hline
\end{tabular}

Notes: Perceived quality: Multivariate tests significant at 0.000; F = $19.06(3,258)$; Partial Eta Squared $=0.181$

Brand awareness: Multivariate tests significant at 0.000; F $=25.55(3,258)$; Partial Eta Squared $=0.229$

Significant at 0.01 level; $\mathrm{SD}=$ Standard deviation 
Table 3. MANOVA results - univariate tests - within-subjects effects for Malaysian fast food brands

\begin{tabular}{|c|c|c|c|c|c|c|c|c|c|}
\hline Effects & Dependent Variables & Mean & SD & $\mathbf{N}$ & $\boldsymbol{F}$ & $d f$ & Error $d f$ & $p$ & $\begin{array}{l}\text { Partial Eta } \\
\text { Squared }\end{array}$ \\
\hline \multirow{9}{*}{$\begin{array}{l}\text { Perceived } \\
\text { quality } \\
(P Q)\end{array}$} & Brand trust & & & & 37.11 & 3 & 263 & $0.00 *$ & 0.124 \\
\hline & High PQ & 4.67 & 0.07 & 134 & & & & & \\
\hline & Low PQ & 4.08 & 0.07 & 133 & & & & & \\
\hline & $\begin{array}{l}\text { Attitudinal brand } \\
\text { loyalty }\end{array}$ & & & & 57.24 & 3 & 263 & $0.00 *$ & 0.179 \\
\hline & High PQ & 4.45 & 0.07 & 134 & & & & & \\
\hline & Low PQ & 3.67 & 0.07 & 133 & & & & & \\
\hline & Overall Brand equity & & & & 34.85 & 3 & 263 & $0.00 *$ & 0.117 \\
\hline & High PQ & 4.28 & 0.08 & 134 & & & & & \\
\hline & Low PQ & 3.61 & 0.08 & 133 & & & & & \\
\hline \multirow{9}{*}{$\begin{array}{l}\text { Brand } \\
\text { awareness } \\
(B A)\end{array}$} & Brand trust & & & & 62.24 & 3 & 263 & $0.00^{*}$ & 0.191 \\
\hline & High BA & 4.75 & 0.07 & 134 & & & & & \\
\hline & Low BA & 3.99 & 0.07 & 133 & & & & & \\
\hline & $\begin{array}{l}\text { Attitudinal brand } \\
\text { loyalty }\end{array}$ & & & & 68.64 & 3 & 263 & $0.00 *$ & 0.207 \\
\hline & High BA & 4.48 & 0.07 & 134 & & & & & \\
\hline & Low BA & 3.63 & 0.07 & 133 & & & & & \\
\hline & Overall Brand equity & & & & 59.13 & 3 & 263 & $0.00 *$ & 0.184 \\
\hline & High BA & 4.38 & 0.08 & 134 & & & & & \\
\hline & Low BA & 3.51 & 0.08 & 133 & & & & & \\
\hline
\end{tabular}

Notes: Perceived quality: Multivariate tests significant at 0.000; $\mathrm{F}=19.48(3,261)$; Partial Eta Squared $=0.183$

Brand awareness: Multivariate tests significant at $0.000 ; \mathrm{F}=26.04(3,261)$; Partial Eta Squared $=0.230$

Significant at 0.01 level; $\mathrm{SD}=$ Standard deviation

The Cronbach's alpha of the variables ranged from 0.90 to 0.94 which satisfied the cut-off value of 0.70 , which indicated the internal consistency of the constructs (Nunnally, 1978). A one-way between-groups multivariate analysis of variance was conducted to investigate brands origin differences in consumer-based brand equity. Preliminary assumption testing was conducted to check for normality, linearity, univariate and multivariate outliers, homogeneity of variance-covariance matrices, and multicolinearity, with no violations noted. There was a statistically significant difference between global and Malaysian brands on the combined dependents variables: $\mathrm{F}(5,525)=33.76, \mathrm{p}=0.000$; Wilks' Lambda $=0.757$; partial eta squared $=0.243$. The result represents 24.3 per cent of the variance in consumer-based brand equity scores explained by brands origin. When the results for the dependents variables were considered separately, the only difference to reach statistical significance were perceived quality: $\mathrm{F}(1,529)=13.71, \mathrm{p}=0.000$; partial eta squared $=0.025$, brand awareness: $\mathrm{F}(1,529)=70.90$, $\mathrm{p}=0.000$; partial eta squared $=0.118$, and overall brand equity: $\mathrm{F}(1,529)=9.54, \mathrm{p}=0.000$; partial eta squared $=0.018$. An inspection of the mean scores indicated that Malaysian brands reported higher levels of perceived quality $(\mathrm{M}=4.51, \mathrm{SD}=0.78)$ than global brands $(\mathrm{M}=4.26, \mathrm{SD}=0.82)$. On the other hand, global brands reported higher levels of brand awareness $(\mathrm{M}=4.78, \mathrm{SD}=0.83)$ and overall brand equity $(\mathrm{M}=4.23, \mathrm{SD}=1.01)$ than Malaysian brands, $(\mathrm{M}=4.13, \mathrm{SD}=0.94)$ and $(\mathrm{M}=3.95, \mathrm{SD}=1.07)$ respectively. Out of the three statistical significance results, only the effect of brand origin was shown to have moderate variance effect on the brand awareness as indicated by partial eta squared value of 0.118 (Cohen 1988). Therefore, H1a to H1e were supported.

In order to test $\mathrm{H} 2$, the median values were determined for the purpose to classify perceived quality and brand awareness into high and low groups, as independent variables. According to Lane (2000), all respondents needed 
to be familiar and have the experience with the category and there had to be potential for variance in the perceived emotional significance of brands in the category. Furthermore, the high and low level of brand awareness and perceived quality could not be easily observed or detected by researchers. Thus, the findings had proposed to split the data based on the median of aggregated measurement items. In the global brands, the median of perceived quality was 4.11 and brand awareness 4.88. In the Malaysian brands, the median of perceived quality was 4.56 and brand awareness 4.25. Subsequently, two separated analyses of two-way between-groups MANOVA for global and Malaysian brand were performed. Preliminary assumption testing was conducted to check for normality, linearity, univariate and multivariate outliers, homogeneity of variance-covariance matrices, and multicolinearity, with no violations noted. There were statistically significant difference between high-low level of perceived quality (PQ) and brand awareness (BA) on the dependents variables in global brands sample $\{\mathrm{PQ}$ effect: $\mathrm{F}(3,258)=19.06, \mathrm{p}=0.000$; Wilks' Lambda $=0.819$; partial eta squared $=0.181$, BA effect: $\mathrm{F}(3,258)=25.55, \mathrm{p}=0.000$; Wilks' Lambda $=0.771$; partial eta squared $=0.229\}$, and in Malaysian brands sample $\{\mathrm{PQ}$ effect: $\mathrm{F}(3,261)=19.48, \mathrm{p}=0.000$; Wilks' Lambda $=0.817$; partial eta squared $=0.183$, BA effect: $F(3,261)=26.04, p=0.000$; Wilks' Lambda $=0.770$; partial eta squared $=0.230\}$. All the results for the dependents variables were shown to reach statistical significance as indicated in Table II and Table III. The result also had indicated a high level (PQ and BA) reported to have higher mean scores for brand trust, attitudinal brand loyalty and overall brand equity than low level, consistent across global and Malaysian brands sample. The effect sizes for each dependent variable was somewhat higher for BA when compared to PQ on either the multivariate or univariate tests across global and Malaysian brands sample. For instance, with the multivariate tests the eta squared values for BA are 0.229 (global brands) and 0.230 (Malaysian brands), but the PQ was lower (global brands: 0.181; Malaysian brands: 0.183). Similar patterns could be seen on the univariate tests. That is, BA had proven to have greater effect on the variance of dependent variables as compared to PQ. As a result, $\mathrm{H} 2$ was supported.

\section{Conclusion}

The result of this study revealed that the dimensions of consumer-based brands equity could be reasonably related to category specific. The developments of the overall brand equity and brand awareness are highly explained by the specification of category, while not essentially for perceived quality, brand trust and attitudinal brand loyalty. The core concept of brand equity was to gain the brand commitment that resulted from consumer's response of generally supremacy of a particular product or service category carrying that brand name. In other words, it refers to the "ultimate" brand choice of a consumer in a specific category. For instance, hamburger for McDonald's, fried chicken for KFC, pizza for Pizza Hut, Root Beer for A\&W. Consequently, this could provide an opportunity for charging a price premium and to ensure corporate profitability. Furthermore, it also enhances the consumer mind share, associative network memory, encouraging affective response, and brand relationships of a particular fast food brand when there was a high relevancy of consumer categorization processes along with the marketing efforts.

Researchers and practitioners should exercise caution in the understanding of these findings. This study emphasized that brand awareness had contributed greater variance on brand trust, attitudinal brand loyalty, and overall brand equity than perceived quality, but these results do not indicate that fast food managers could compromise the importance of perceived quality. The main purpose of this study was to provide a better guidance for brand strategy and brand tracking; highlighting the natural drawback on focusing the perception of brand quality that have been exercised by many Malaysian fast food brands. Such branding strategy heavily focused on the economic-perspective of consumer-based brand equity, which indicated that brand equity should be evaluated based on the brand credibility and added value (Erdem \& Swait, 1998). However, Malaysian fast food managers have to realize that psychological-based brand equity was beyond consumers' expected utility, which should include personal meanings and images that had existed in consumers' heart and soul within a specific category (Aaker, 1997; Keller, 1998).

Brand trust had been recognized as a prominent variable that had led to long-term relationship with customers, which affected attitudinal brand loyalty in a positive way (Chiou \& Droge, 2006; Flavian et al., 2006; Sichtmann, 2007; Martzler et al., 2008; Rauyruen \& Miller, 2007). On the other hand, many studies had proven that brand loyalty had significant effect on brand equity (Baldauf et al., 2003; Gil et al., 2007; Kim \& Kim, 2004; Norjaya et al., 2007; Tong \& Hawley, 2009; Yoo et al., 2000); indicated the essential role of developing brand loyalty in brand equity creation. Thus, focusing on brand trust and attitudinal brand loyalty was usually seen as central to the success of marketing campaigns. However, the study showed that both brand trust and attitudinal brand loyalty were not explained by category specific. In other words, consumers would unconsciously trust and be loyal to a variety of brands within the same category. Namely, it allows competitors to enact to switching behaviours 
through counter-argumentation especially when the brand was not widely distributed. As a result, fast food managers had to establish the most relevant knowledge pertaining to the brand; which clearly had identified the product or service categories that was offered, as compared to other competitors.

\section{Managerial Implication}

In order to enhance brand awareness, Malaysian fast food managers had established the most relevant brand input in consumers' mind; which clearly had identified the product or service categories that was offered, as compared to other competitors (Tan et al., 2012b). Therefore, the identification of the brand position and category served as a necessity and crucial marketing plan in creating brand equity. According to Keller's (1998) consumer categorization processes were employed as the technique in registering a brand in the consumers' memory. Firstly, fast food managers had to decide which consumer categorization processes had to be targeted for brand awareness programs, such as product class information, product category and product type information (Keller, 1998). Next, the design of programs highlighted the visibility of brand information as when compared to brands. Consumers had on top-of-mind and sufficient mind share of a particular fast food brand when there was a high relevancy of consumer categorization processes along with the marketing efforts. In addition to that, the design of brand awareness programs had to be focused on satisfying consumers' affective needs. That is, fast food managers had to illustrate the satisfaction on affective response, such as pleasure, relax, excitement, and arousal, social class, self-emotional, lifestyle, trustworthiness, and self-concept instead of focusing on food quality. Besides, Malaysian fast food managers had to focus on the simplification of strategies (use of heuristics) where consumers tended to choose a well-known brand as it facilitated the choice process, and displayed a tendency to accept more repetitive advertising by a familiar brand than from an unknown or unfamiliar brand. Thus, pioneer brands always had tremendous advantages when it came to conquer the permanent positive memory codes. Therefore, building the highest possible degree of brand awareness had been based on targeted category of new fast food brands as it ensured the successfulness of marketing efforts (Tan et al., 2012b).

\section{Limitation}

The main limitation in this study was the coverage of category specification. According to Keller (1998), consumer categorization processes could be explained by product class information, product category, product type information, and brand information. However, in this study, only product category was examined. Future studies should include greater scope of investigation, and examine the possible interaction effects of brand awareness and overall brand equity with different level of consumer categorization processes. Besides, brand image - an essential element in marketing research and vital dimension of brand equity was excluded, this is because brand image was considered as a complex construct due to its conceptualization (Keller, 1993). Another limitation of this study was the use of cross-sectional data. Thus, this study only investigated the variance between brand equity dimensions at a given time and period. A longitudinal study should be designed, using psychology involving a series of observations made over long period of time. Future research could explore the possibility of a longitudinal study through repeated observations, and invariance test across different samples should be conducted to make certain that the results remained equivalent.

\section{References}

Aaker, D. A. (1991). Managing brand equity. New York: Free Press.

Aaker, D. A. (1996). Measuring brand equity across products and markets. New York: Free Press.

Aaker, J. L. (1997). Dimensions of brand personality. Journal of Marketing Research, 34, 347-356. http://dx.doi.org/10.2307/3151897

Anderson, E., \& Weitz, B. (1989). The use of pledges to build and sustain commitment in distribution channels. Journal of Marketing Research, 29(1), 18-34. http://dx.doi.org/10.2307/3172490

Aseambankers (2007). Equity Focus-KFC Holdings (M) Berhad. Retrieved from http://www.maybank2e.net/economic_library/equity_focus_11Jan07\%28KFC\%20Initiating\%29.pdf

Ashkanasy, N. M., \& Nicholson, G. J. (2003). Climate of fear in organisational settings: Construct definition, measurement and a test of theory. Australian Journal of Psychology, 55(1), 24-29. http://dx.doi.org/10.1080/00049530412331312834

Auty, R. (2001). Being like or being liked: identity vs. approval in a social context. Advances in Consumer Research, 28, 235-241.

Back, K. J. (2005). The effects of image congruence on customers' brand loyalty in the upper middle-class hotel 
industry. Journal of Hospitality \& Tourism Research, 29(4), 448-467. http://dx.doi.org/10.1177/1096348005276497

Baldauf, A., Cravens, K. S., \& Binder, G. (2003). Performance consequences of brand equity management: Evidence from organizations in the value chain. Journal of Product \& Brand Management, 12(4), 220-236. http://dx.doi.org/10.1108/10610420310485032

Block, J. P., Scribner, R. A., \& DeSalvo, K. B. (2004). Fast food, race/ethnicity, and income: A geographic analysis. American Journal of Preventive Medicine, 27(3), 211-217.

Bloemer, J. M. M., \& Kasper, H. D. P. (1995). The complex relationship between consumer satisfaction and brand loyalty. Journal of Economic Psychology, 16(2), 311-329. http://dx.doi.org/10.1016/0167-4870(95)00007-B

Brand Equity. (2011). Malaysian shoppers are the 2nd most prolific, 3, 22-23.

Buil, I., De Chernatony, L., \& Martínez, E. (2008). A cross-national validation of the consumer-based brand equity scale. Journal of Product \& Brand Management, 17(6), 384-392. http://dx.doi.org/10.1108/10610420810904121

Burdette, H. L., \& Whitaker, R. C. (2004). Neighborhood playgrounds, fast food restaurants, and crime: relationships to overweight in low-income preschool children. Preventive Medicine, 38(1), 57-63. http://dx.doi.org/10.1016/j.ypmed.2003.09.029

Caruana, A. (2002). Service loyalty: The effects of service quality and the mediating role of customer satisfaction. European Journal of Marketing, 36(6/7), 811-828. http://dx.doi.org/10.1108/03090560210430818

Chaudhuri, A., \& Holbrook, M. B. (2001). The chain of effects from brand trust and brand affect to brand performance: the role of brand loyalty. Journal of Marketing, 65(April), 81-93. http://dx.doi.org/10.1509/jmkg.65.2.81.18255

Chiou, J. S., \& Droge, C. (2006). Service quality, trust, specific asset investment, and expertise: Direct and indirect effects in a satisfaction-loyalty framework. Journal of the Academy of Marketing Science, 34(4), 613-627. http://dx.doi.org/10.1177/0092070306286934

Chiou, J. S., Droge, C., \& Hanvanich, S. (2002). Does customer knowledge affect how loyalty is formed? Journal of Services Research, 5(2), 113-25. http://dx.doi.org/10.1177/109467002237494

Cobb-Walgren, C. J., Beal, C., \& Donthu, N. (1995). Brand equity, brand preferences, and purchase intent. Journal of Advertising, 24(3), 25-40.

Dabholkar, P. (1995). A contingency framework for predicting causality between customer satisfaction and service quality. Advances in Consumer Research, 22, 101-106.

Dacin, P. A., \& Smith, D. C. (1994). The effect of brand portfolio characteristics on consumer evaluations of brand extensions. Journal of Marketing Research, 31(2), 229-242. http://dx.doi.org/10.2307/3152196

Donovan, R. J., Rossiter, J. R., Marcoolyn, G., \& Nesdale, A. (1994). Store atmosphere and purchasing behavior. Journal of Retailing, 70(3), 283-294. http://dx.doi.org/10.1016/0022-4359(94)90037-X

Erdem, T., \& Swait, J. (1998). Brand equity as a signaling phenomenon. Journal of Consumer Psychology, 7(2), 131-157. http://dx.doi.org/10.1207/s15327663jcp0702_02

Esch, F.-R., Langner, T., Schmitt, B. H., \& Geus, P. (2006). Are brands forever? How brand knowledge and relationships affect current and future purchases. Journal of Product \& Brand Management, 15(2), 98-105. http://dx.doi.org/10.1108/10610420610658938

Flavián, C., Guinalíu, M., \& Gurrea, R. (2006). The role played by perceived usability, satisfaction and consumer trust on website loyalty. Information and Management, 43(1), 1-14. http://dx.doi.org/10.1016/j.im.2005.01.002

Gil, R. B., Andrés, E. F., \& Salinas E. M. (2007). Family as a source of consumer-based brand equity. Journal of Product \& Brand Management, 16(3), 188-199. http://dx.doi.org/10.1108/10610420710751564

Hafidz, M. M., Daljit D., \& Eugene, M. (2010). Hey, big ad spenders! Retrieved from http://biz.thestar.com.my/news/story.asp?sec=business\&file=/2010/12/11/business $/ 7571720$

Halim, W. Z., \& Hamed, A. B. (2005). Consumer purchase intention at traditional restaurant and fast food restaurant. Proceedings of the Australian and New Zealand Marketing Academy (ANZMAC) Conference, 
Australia, 107-112.

Henry, T., Catherine, C., \& Ada, L. (2010). An exploratory study of the relationship between customer-based casino brand equity and firm performance. International Journal of Hospitality Management, 29, 754-757. http://dx.doi.org/10.1016/j.ijhm.2009.08.001

Kam, R. (2008). Demand still strong for 1901 franchise. Retrieved from http://biz.thestar.com.my/news/story.asp?file=/2008/9/15/business/2016675\&sec=business

Keller, K. L. (1993). Conceptualizing, measuring, and managing customer-based brand equity. Journal of Marketing, 57(1), 1-22. http://dx.doi.org/10.2307/1252054

Keller, K. L. (1998). Strategic brand management: Building, measuring, and managing brand equity. New Jersey: Prentice-Hall.

Keller, K. L. (2003). Building, measuring and managing brand equity (2nd ed.). Prentice-Hall, Upper Saddle River, NJ.

Kim, H. B., \& Kim, W. G. (2005). The relationship between brand equity and firms' performance in luxury hotels and chain restaurants. Tourism Management, 26, 549-560. http://dx.doi.org/10.1016/j.tourman.2004.03.010

Kim, W. G., \& Kim, H. B. (2004). Measuring customer-based restaurant brand equity: Investigating the relationship between brand equity and firms' performance. Cornell Hotel \& Restaurant Administration Quarterly, 45(2), 115-131. http://dx.doi.org/10.1177/0010880404264507

Lane, V. L. (2000). The impact of ad repetition and ad content on consumer perceptions of incongruent extensions. Journal of Marketing, 64, 80-91. http://dx.doi.org/10.1509/jmkg.64.2.80.17996

Lassar, W., Mittal, B., \& Sharma, A. (1995). Measuring customer-based brand equity. Journal of Consumer Marketing, 12(4), 11-19. http://dx.doi.org/10.1108/07363769510095270

Loken, B., \& Roedder J. D. (1993). Diluting brand beliefs: When do brand extensions have a negative impact? Journal of Marketing, 57(3), 71-84. http://dx.doi.org/10.2307/1251855

Marshall Cavendish. (2009). Food industry in Malaysia: An overview. Retrieved from www.foodbizmalaysia.com/IndProf\%5CMFBD\%5CMFBD_2009_IP01.pdf

Matzler, K., Grabner-Krauter, S., \& Bidmon, S. (2008). Risk aversion and brand loyalty: The mediating role of brand trust and brand affect. Journal of Product \& Brand Management, 17(3), 154-162. http://dx.doi.org/10.1108/10610420810875070

Michell, P., King, J., \& Reast, J. B. (2001). Values related to industrial products. Industrial Marketing Management, 30, 415-425. http://dx.doi.org/10.1016/S0019-8501(99)00097-8

Milgrom, P., \& Roberts, J. (1986). Price and advertising signals of product quality. Journal of Political Economy, 55(August), 10-25.

Morgan, R. M., \& Hunt, S. D. (1994). The commitment-trust theory of relationship marketing. Journal of Marketing, 58(3), 20-38. http://dx.doi.org/10.2307/1252308

Narayandas, N. (1996). The link between customer satisfaction and customer loyalty: An empirical investigation. Working paper of Harvard Business School.

Norzalita Abd A., \& Norjaya Mohd Y. (2010). Analyzing the brand equity and resonance of banking services: Malaysian consumer perspective. International Journal of Marketing Studies, 2(2), 180-189.

Nunnally, J. C. (1978). Psychometric Theory. New York: McGraw-Hill.

Pallant, J. (2005). SPSS Survival Manual (2nd ed.). McGrawhill, Open University Press.

Park, S. H. (2009). The antecedents and consequences of brand image: Based on Keller's customer-based brand equity. Unpublished doctoral dissertation, Columbus, US.

Perez, M, E., Padgett, D., \& Burgers, W. (2011). Intergenerational influence on brand preferences. Journal of Product \& Brand Management, 20(1), 5-13. http://dx.doi.org/10.1108/10610421111107978

Rauyruen, P., \& Miller, K. (2007). Relationship quality as a predictor of B2B customer loyalty. Journal of Business Research, 60(1), 21-31. http://dx.doi.org/10.1016/j.jbusres.2005.11.006

Rowley, J. (2005). The four Cs of customer loyalty. Marketing Intelligence \& Planning, 23(6), 574-81. http://dx.doi.org/10.1108/02634500510624138 
Russell-Bennett, R., McColl-Kennedy, J. R., \& Coote, L. V. (2007). Involvement, satisfaction, and brand loyalty in a small business services setting. Journal of Business Research, 60(12), 1253-1260. http://dx.doi.org/10.1016/j.jbusres.2007.05.001

Sichtmann, C. (2007). An analysis of antecedents and consequences of trust in a corporate brand. European Journal of Marketing, 41(9-10), 999-1015. http://dx.doi.org/10.1108/03090560710773318

Slattery, M. L., Boucher, K. M., Caan, B. J., Potter, J. D., \& Ma, K. N. (1998). Eating patterns and risk of colon cancer. American Journal of Epidemiology, 148(1), 4-16. http://dx.doi.org/10.1093/aje/148.1.4-a

Sujan, M., \& Dekleva, C. (1987). Product categorization and inference making: Some implications for comparative advertising. Journal of Consumer Research, 14(3), 372-8. http://dx.doi.org/10.1086/209120

Tan, T. M. (2012). Facebook fans counts: Malaysian fast food brands. Retrieved from http://www.brandattachment.com/marketing_concepts/Facebook_Fans_Counts_Malaysian_Fast_Food_Bra nds

Tan, T. M., Hishamuddin I., \& Devinaga, R. (2011). Hierarchical chain of consumer-based brand equity: Review from the fast food industry. International Business \& Economics Research Journal, 10(9), 67-80.

Tan, T. M., Liew, T. W., William, L., Michelle, O. B. F., \& Tan, S. M. (2012a). Consumer-based brand equity in the service shop. International Journal of Marketing Studies, 4(4), 60-77. http://dx.doi.org/10.5539/ijms.v4n4p60

Tan, T. M., Hishamuddin I., \& Devinaga, R. (2012b). Malaysian fast food brand equity. Germany: Lap Lambert Academic Publishing.

The Star (2010). Contest to mark Marrybrown's 30th anniversary. Retrieved from $\mathrm{http}: / /$ thestar.com.my/metro/story.asp?sec=central\&file=/2010/12/13/central/7585940

Tong, X., \& Hawley, J. M. (2009). Measuring customer-based brand equity: empirical evidence from the sportswear market in China. Journal of Product \& Brand Management, 18(4), 262-271. http://dx.doi.org/10.1108/10610420910972783

Valkenburg, P. M., \& Buijzen, M. (2005). Identifying determinants of young children's brand awareness. $\begin{array}{llll}\text { Journal of Applied Developmental } & \text { Psychology, } & \text { 26(4), }\end{array}$ http://dx.doi.org/10.1016/j.appdev.2005.04.004

Wood, L. (2004). Dimensions of brand purchasing behaviour: Consumers in the 18-24 age group. Journal of Consumer Behaviour, 4(1), 9-24. http://dx.doi.org/10.1002/cb.154

Yoo, B., Donthu, N., \& Lee, S. (2000). An examination of selected marketing mix elements and brand equity. Academy of Marketing Science, 28(2), 195-212. http://dx.doi.org/10.1177/0092070300282002

Zeithaml, V. A. (1988). Consumer perceptions of price, quality, and value: A means-end model and synthesis of evidence. Journal of Marketing, 52(July), 2-22. http://dx.doi.org/10.2307/1251446

Zinnbauer, M., \& Bakay, Z. (2004). Modelling brand equity in a modern business contex. VIIth World Congress SAM/ IFSAM. Proceedings in the International Federation of Scholarly Associations of Management. Retrieved from www.handels.gu.se/ifsam/Streams/etm\%20isy/241\%20final.pdf 